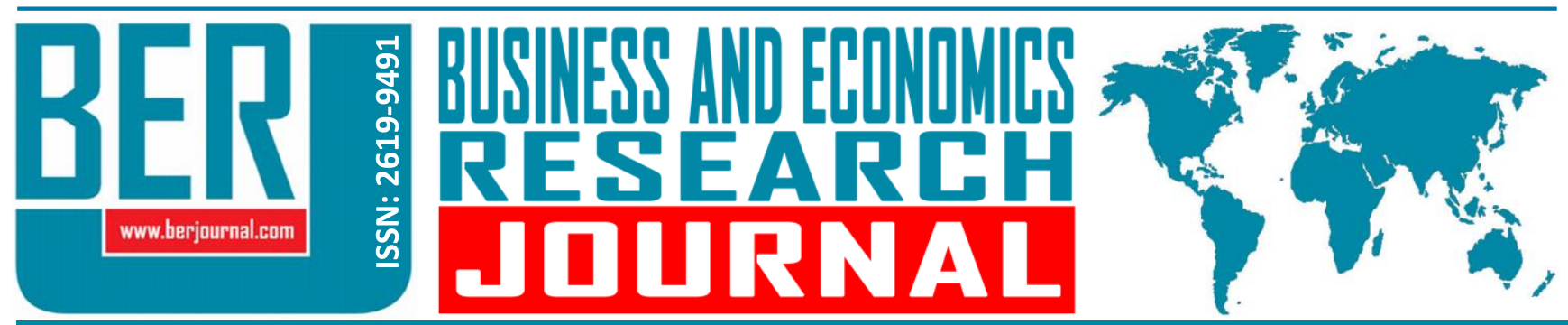

Business and Economics Research Journal Vol. 10, No. 5, 2019, pp. 1179-1187 doi: 10.20409/berj.2019.229

\title{
Project Selection Method Based on Balanced Scorecard Framework
}

\section{Duygu Ece Yilmaz ${ }^{\mathrm{a}}$, Figen Antmen ${ }^{\mathrm{b}}$}

Abstract: Project selection is one of the most important decisions for an organisation to achieve its goals and manage its resources effectively. This study aims to develop a project evaluation method using the balanced scorecard (BSC) dimensions. Although the BSC technique has been used in combination with other methods in various fields, such as supplier qualification and project evaluation, the dimensions of the BSC method have not been defined as parameters in the mathematical model of a knapsack problem. By doing so and considering time and budget constraints, the developed mathematical model selects the most suitable projects using the weighted sum of parameters. The performance of the developed model was tested with randomly generated sample data. Sixteen alternatives were assessed to determine the impact of varying dimension coefficients, budgets, project durations and labour requirement constraints to be established by organisations. The model generates consistent results and can be used by organisations at the project and investment evaluation step.
Keywords: Project Selection, Balanced Scorecard, Knapsack Problem, Decision Support Systems

JEL: G11, D81, C61

Received : 06 May 2019

Revised : 29 June 2019

Accepted : 20 August 2019

Type : Methodologies

\section{Introduction}

The rapid progress of technological development has caused significant changes in production methods, processes and machines, allowing for the constant increase in the amount and quality of mass production. Due to the increasing quality and production standards, competition between organisations is growing. Meeting the amount and quality standards is no longer sufficient for the survival of an organisation; it is also necessary to develop and implement correct strategies, take intellectual capital into account and effectively utilise physical and financial capital (Basık, 2012).

Proper determination of performance criteria is necessary to progress in line with the vision and strategic goals of the organisation. The balanced scorecard (BSC) technique, introduced by Kaplan and Norton, correlates the success criterion with short and long-term goals (Kaplan \& Norton, 1992). The success criteria, to be set out in compliance with the strategic goals, provide integrity of the operation and further improvements.

The BSC technique classifies the basic goals of an organisation and defines success criteria under four categories (Kaplan \& Norton, 1992):

- Financial perspective,

b Asst. Prof., PhD., Cukurova University Faculty of Engineering and Architecture, Department of Industrial Engineering, Adana, Turkiye, fantmen@cu.edu.tr (ORCID ID: 0000-0001-8475-1300) 
- Customer perspective,

- Internal business perspective, and

- Learning and growth perspective.

The financial perspective addresses the short and long-term goals and success criteria related to the financial success of the organisation. Financial criteria can be used to determine the success of past investment projects, customers view and institutional strategies (Basık, 2012).

The customer perspective is directly related to customer perception created by obtaining the strategic goals of the operation. The number of customers and their satisfaction, market share and customer loyalty can be addressed within these targets (Kaygusuz, 2005).

The internal business perspective addresses the realisation of the financial- and customer-focused goals, new procedures to be developed and any improvements and success criteria defined for these goals. Here, all activities and services from pre-production through after-sale services can be evaluated and goals and success criteria can be defined. It is necessary to focus on internal business procedures to be established, renewed and/or improved to reach the success criteria established in the financial and customer perspectives (Güner, 2008)

The learning and growth perspective includes the targets and success criteria defined to improve the human resources of the entity. In today's competitive environment, prospective employees must demonstrate creativity, continuous improvement and efficient utilisation of information; employees' skills and abilities, intellectual capabilities and personal contributions are crucial. Abilities and qualifications of each employee are required for obtaining the learning and growth goals. Success criteria are then defined accordingly.

The above-mentioned categories of BSC is considered to cover all aspects of any company. Therefore, a BSC is prepared via the following steps in organisations (Basık, 2012):

1. Define the strategic goals of the organisation,

2. Correlate success criteria with defined goals to be used for measurement of achievements,

3. Define the success criteria,

4. Estimate the outcomes of achieving the goals and set forth the expectations,

5. Define the responsible employee and their responsibilities,

6. Schedule the succeeding steps.

Balanced scorecard tables are used by many international organisations either alone or in combination with other techniques to measure performances and manage strategies. Similar to other management tools, however, it is not always possible to quantify the results or demonstrate reproducibility in every organisation. Culture, operational and commercial conditions may cause this technique to not be suitable in every organisation (Güner, 2008). Furthermore, various limitations, constraints and other obstacles may be met during the implementation phase. Sufficient time must be allotted for successful implementation; to review the cause and effect relations very closely and to develop the support and participation of all upper and lower level employees for the entire processing period.

Project implementation and investment decisions are among the most important decisions for the development and existence of an organisation. Increasing options, limitations and other constraints make it difficult to ensure projects are in line with the organisation's strategy and success criteria. The use of the BSC method in combination with the other methods allows for an easier decision-making process. It can be used to specify the vision and strategy of an organisation during the evaluation phase of project proposals and to set the most suitable evaluation criteria. This study aims to develop a method for project evaluation using the BSC method. Unlike the studies in literature, a comprehensive mathematical model that is easy to change and adapt according to organisations' needs are constructed using BSC dimensions. Hence, the main 
contribution of this paper is using the dimensions of the BSC method as parameters in the mathematical model and establishing an adaptive project selection method.

In order to model the project evaluation process, the BSC method is integrated into a knapsack problem model, which is a common combinatorial optimisation method for selection based on weight constraints. This method is constructed to simplify decision making on project selection and to give managers a better insight of which of the project options are more appropriate for their organisation's goals.

This paper is organised as follows. Section 2 includes review of the previous studies in literature. Section 3 introduces the mathematical model of the established method and explain notations used in this paper. Section 4 then explains model outputs and findings of the sensitivity analysis. Finally, Section 5 presents the conclusions of the study.

\section{Literature Review}

The BSC method was proposed by Kaplan and Norton to identify problem areas and specify areas for improvement within organisations (Kaplan \& Norton, 1992). This method has often been used since then as an effective tool to progress the organisation in line with its mission and strategy by defining targets and criteria suitable for each unit.

According to Bailey, Chow and Haddad (1999), BSCs are used in varying fields, from the service and production sectors to international accounting firms, and their usage presents a variety of benefits, as they can:

- Encourage the effective formulation in the implementation of organisational strategies,

- Make updating organisational strategies easier and increase their visibility,

- Improve communication within the organisation,

- Improve compliance between institutional and personal goals,

- Harmonise short-term operational plans with long-term strategies, and

- Ensure that performance evaluation measurements conform to long-term strategies.

Automation of BSC implementation is a recent trend. By reviewing implementation timelines, Güner (2008) demonstrated that the BSC method takes too much time to apply and thus is not applicable for every type of organisation.

Kaygusuz (2005) emphasised that the BSC technique should be applied to top management as well as to lower levels. All employees should thus participate in the target-setting procedure, not only top management, to encourage understanding and embracing of the defined targets. Any improvements to the production environment influences customers' satisfaction and this satisfaction then affects the firm's financial performance and strategy. Use of the BSC method allows the relationship between strategy and applications to be provided, makes it easier to define new performance criteria and determines cause and effect relationships.

BSC has been used in various areas from supplier qualification and performance evaluation to project selection in combination with various other methods such as data envelopment analysis (DEA), fuzzy inference system (FIS), analytical hierarchal processes (AHP), fuzzy analytical hierarchal processes (FAHP), analytic network process (ANP), decision-making trial and evaluation laboratory (DEMATEL) and binary programming. Studies that are examined are shown below in Table 1. 
Table 1. Literature Review

\begin{tabular}{|c|c|c|c|c|}
\hline Year & Author(s) & Title & Method & Problem \\
\hline 2007 & $\begin{array}{l}\text { Bhagwat \& } \\
\text { Sharma }\end{array}$ & $\begin{array}{l}\text { Performance measurement of supply } \\
\text { chain management: A balanced } \\
\text { scorecard approach }\end{array}$ & BSC \& DEA & $\begin{array}{l}\text { Performance } \\
\text { evaluation of } \\
\text { suppliers }\end{array}$ \\
\hline 2008 & $\begin{array}{l}\text { Eilat, Golany \& } \\
\text { Shtub }\end{array}$ & $\begin{array}{l}\text { R\&D project evaluation: An integrated } \\
\text { DEA and balanced scorecard approach }\end{array}$ & BSC \& DEA & $\begin{array}{l}\text { Research \& } \\
\text { Development } \\
\text { project evaluation }\end{array}$ \\
\hline 2010 & $\begin{array}{l}\text { Asosheh, } \\
\text { Nalchigar \& } \\
\text { Jamporazmey }\end{array}$ & $\begin{array}{l}\text { Information technology project } \\
\text { evaluation: An integrated data } \\
\text { envelopment analysis and balanced } \\
\text { scorecard approach }\end{array}$ & BSC \& DEA & $\begin{array}{l}\text { Information } \\
\text { technology project } \\
\text { evaluation }\end{array}$ \\
\hline 2012 & Chang \& Lee & $\begin{array}{l}\text { A fuzzy DEA and knapsack formulation } \\
\text { integrated model for project selection }\end{array}$ & $\begin{array}{l}\text { DEA \& } \\
\text { Knapsack }\end{array}$ & Project selection \\
\hline 2014 & $\begin{array}{l}\text { Shafiee, Lotfi \& } \\
\text { Saleh }\end{array}$ & $\begin{array}{l}\text { Supply chain performance evaluation } \\
\text { with data envelopment analysis and } \\
\text { balanced scorecard approach }\end{array}$ & BSC \& DEA & $\begin{array}{l}\text { Performance } \\
\text { measurement of } \\
\text { suppliers }\end{array}$ \\
\hline 2017 & $\begin{array}{l}\text { Simplicio, Gomes } \\
\text { \& Romao }\end{array}$ & $\begin{array}{l}\text { Projects Selection and Prioritization: A } \\
\text { Portuguese Navy Pilot Model. } \\
\text { Procedia Computer Science }\end{array}$ & $\begin{array}{l}\text { Multi-criteria } \\
\text { analysis }\end{array}$ & Project Selection \\
\hline 2017 & $\begin{array}{l}\text { Mostamand, } \\
\text { Hajiagha \& } \\
\text { Daneshvar }\end{array}$ & $\begin{array}{l}\text { Selecting Strategies by Considering } \\
\text { Budget Limitation: A Hybrid Algorithm } \\
\text { of SWOT-DEMATEL-ANP and Binary } \\
\text { Programming with Grey Information }\end{array}$ & $\begin{array}{l}\text { SWOT, } \\
\text { DEMATEL, ANP } \\
\text { \& Binary } \\
\text { Programming }\end{array}$ & Project Selection \\
\hline 2017 & $\begin{array}{l}\text { Tan, Zhang \& } \\
\text { Khodaverdi }\end{array}$ & $\begin{array}{l}\text { Service Performance Evaluation Using } \\
\text { Data Envelopment Analysis and } \\
\text { Balance Scorecard Approach }\end{array}$ & BSC \& DEA & $\begin{array}{l}\text { Performance } \\
\text { evaluation of } \\
\text { suppliers }\end{array}$ \\
\hline 2018 & $\begin{array}{l}\text { Singh, Olugu, } \\
\text { Musa \& Mahat }\end{array}$ & $\begin{array}{l}\text { Fuzzy-based sustainability evaluation } \\
\text { method for manufacturing SMEs using } \\
\text { balanced scorecard framework }\end{array}$ & $\begin{array}{l}\text { BSC \& FIS \& } \\
\text { FAHP }\end{array}$ & $\begin{array}{l}\text { Evaluation of } \\
\text { sustainability }\end{array}$ \\
\hline
\end{tabular}

The BSC method was shown in these studies to offer a useful framework for criteria classification and a flexible basis suitable for almost any type of organisation.

At the project planning stage, BSCs can be used to set up targets, correlate projects to organisational strategies and allot resources within or between projects. At the implementation stage, BSCs can be used to provide relative performance criteria, measure project value under changing conditions and priorities, and aid in determining project outcomes. At the project completion stage, BSCs can be used to find out the best application practices and be a method for improving project processes.

In the developed model, BSC dimensions were assigned as parameters to an established knapsack model. This simple yet effective method can be adapted to represent any organisation by adding new constraints and criteria.

\section{Material and Method}

A mathematical model was first established to evaluate the projects and selection using the dimensions of a BSC table. This model qualifies the most beneficial projects by using the weighted sum of parameters calculated on project scorecard dimensions by taking the time and cost constraints into account. The mathematical model is constructed using the following notations.

$$
\begin{array}{ll}
\mathrm{E}_{\mathrm{ij}}: & j^{\text {th }} \text { dimension point of project } l, \\
\mathrm{~W}_{\mathrm{j}}: & \text { weight assigned to } j^{\text {th }} \text { dimension by the decision maker, } \\
\mathrm{T}: & \text { Total time allocated for all projects, }
\end{array}
$$



$\mathrm{t}_{\mathrm{i}}: \quad$ time required to realise project $i$,
B: total budget reserved for all projects,
Ci: $\quad$ capital required for project $i$,
Ri: $\quad$ success probability assigned to project $i$,
$\mathrm{H}$ : total number of employee assigned for all projects,
$\mathrm{P}_{\mathrm{i}}$ : $\quad$ number of qualified personnel for running phase for project $i$.

The considered decision variables are given below.

$X_{i}=\left\{\begin{array}{l}1, \text { selection of project } i \\ 0, \text { other }\end{array}\right.$

By using the given notation, the following mathematical model is constructed.

Maximise $\mathrm{z}=\sum_{\mathrm{i}} \sum_{\mathrm{j}} \mathrm{E}_{\mathrm{ij}} \mathrm{W}_{\mathrm{j}} \mathrm{X}_{\mathrm{i}}$

For:

$\sum_{i} \mathrm{t}_{\mathrm{i}} \mathrm{X}_{\mathrm{i}} \leq T$

$\sum_{i} \mathrm{C}_{\mathrm{i}} \mathrm{X}_{\mathrm{i}} \leq B$

$\sum_{i} \mathrm{P}_{\mathrm{i}} \mathrm{X}_{\mathrm{i}} \leq H$

$X_{i} \in\{1,0\}$

Thus, the objective function selects the projects with the highest total productivity. Constraints (1), (2), and (3) ensure that the project duration, budget and personnel do not exceed that assigned to the project by the organisation, respectively.

\subsection{Calculation of Parameter $\mathrm{E}_{\mathrm{ij}}$}

One of the most important targets of an organisation is to increase productivity, i.e., increase outputs while using the least amount of resources. The parameter $E_{i j}$, defined as the rate of project output to project inputs, was used to represent the productivity of project $i$ regarding the $j$ dimension. Model inputs include time, manpower and capital required for each project. Expected model outputs in the case of successful application include improvements and gains. Success criteria used for the implementation phase in each dimension are listed in Table 1. The generic calculation of $E_{i j}$ by using success criteria given as follows:

$$
E_{i j}=\frac{(\text { Total Success Criteria } \mathrm{x} \text { Success Probability) }}{\text { (Project Duration } \mathrm{x} \text { Number of Personnel } \mathrm{x} \text { Wages })+ \text { Project Expenses }} \times 1000
$$

A weight constant $W_{j}$ can be assigned to one or more of the dimensions if decision makers are needed. If the company wants to highlight training-development criteria during the evaluating process, a greater weight can be assigned for project evaluation to qualify projects that have a stronger trainingdevelopment view.

The most common success criteria in industrial organisations are listed and grouped according to BSC perspectives as shown in Table 2. The listed criteria are used for calculation of parameters in $\mathrm{E}_{\mathrm{ij}}$. 
Project Selection Method Based on Balanced Scorecard Framework

Table 2. Success Criteria Used for the Calculation of Parameters in $E_{i j}$

\begin{tabular}{|c|c|c|}
\hline Dimension & Target & Success Criteria for Evaluation \\
\hline \multirow{3}{*}{ Financial } & sale increase & $\%$ increase in product sales \\
\hline & cost decrease & $\%$ decrease in unit cost of products \\
\hline & increase in income & $\begin{array}{l}\text { rate of direct project income over project } \\
\text { cost }\end{array}$ \\
\hline \multirow{4}{*}{ Customer } & price reduction & $\%$ decrease in product price \\
\hline & decrease in after sale costs & $\begin{array}{c}\text { \% decrease in after-sale expenses } \\
\text { (maintenance, repair etc.) }\end{array}$ \\
\hline & increase of customer satisfaction & $\%$ points increase in satisfaction surveys \\
\hline & $\begin{array}{l}\text { increase in the number of } \\
\text { customers }\end{array}$ & $\begin{array}{c}\text { rate of new customers over existing } \\
\text { customers }\end{array}$ \\
\hline \multirow{5}{*}{ Internal Business } & increase in process productivity & $\begin{array}{c}\% \text { decrease in the time necessary for } \\
\text { production of product }\end{array}$ \\
\hline & increase in process productivity & $\begin{array}{c}\% \text { decrease in the labour for production (man } \\
\text { or machine hour) }\end{array}$ \\
\hline & improvement in quality & $\begin{array}{c}\% \text { decrease in the number of defective } \\
\text { products }\end{array}$ \\
\hline & improvement in quality & $\begin{array}{l}\% \text { decrease in the amount of scrap or rate of } \\
\text { waste }\end{array}$ \\
\hline & increase in number of products & $\begin{array}{l}\text { increase in the patent rights and number of } \\
\text { products }\end{array}$ \\
\hline \multirow{3}{*}{$\begin{array}{l}\text { Learning and } \\
\text { Growth }\end{array}$} & increase in skills of employee & training hour per employee \\
\hline & increase in skills of employee & $\begin{array}{l}\text { number of new methods, techniques, or } \\
\text { applications to be used }\end{array}$ \\
\hline & increase in employee satisfaction & $\%$ point increase in employee satisfaction \\
\hline
\end{tabular}

Sample data was generated for implementation using MS Office Excel. Possible data were assigned to the success criteria of 13 separate projects. The constructed model was solved using GAMS programming language and was run with the sample project data to analyse the results.

\section{Findings}

Thirteen letters (A, B, C, D..., M) are assigned to each project for notation simplicity. The details and qualities of the projects are shown in Table 3.

Table 3. Project Details

\begin{tabular}{ccccccc}
\hline $\begin{array}{c}\text { Project } \\
\text { Name }\end{array}$ & $\begin{array}{c}\text { Project } \\
\text { Expenses } \\
\text { (USD) }\end{array}$ & $\begin{array}{c}\text { Project } \\
\text { Duration } \\
\text { (Days) }\end{array}$ & $\begin{array}{c}\text { No. Of } \\
\text { Employees } \\
\text { Required }\end{array}$ & $\begin{array}{c}\text { Probability } \\
\text { of Success }\end{array}$ & $\begin{array}{c}\text { Direct } \\
\text { Income } \\
\text { (USD) }\end{array}$ & $\begin{array}{c}\text { Dimensions Contributed by the } \\
\text { Project }\end{array}$ \\
\hline A & 20,000 & 60 & 3 & $95 \%$ & 4,000 & Financial, Learning and Growth \\
\hline B & 57,452 & 245 & 21 & $76 \%$ & 0 & Internal Business, Customer \\
\hline C & 41,016 & 47 & 27 & $71 \%$ & 48,984 & $\begin{array}{c}\text { Financial, Internal Business, } \\
\text { Customer }\end{array}$ \\
\hline
\end{tabular}


Table 3. Project Details (Continued)

\begin{tabular}{ccccccc}
\hline $\begin{array}{c}\text { Project } \\
\text { Name }\end{array}$ & $\begin{array}{c}\text { Project } \\
\text { Expenses } \\
\text { (USD) }\end{array}$ & $\begin{array}{c}\text { Project } \\
\text { Duration } \\
\text { (Days) }\end{array}$ & $\begin{array}{c}\text { No. Of } \\
\text { Employees } \\
\text { Required }\end{array}$ & $\begin{array}{c}\text { Probability } \\
\text { of Success }\end{array}$ & $\begin{array}{c}\text { Direct } \\
\text { Income } \\
\text { (USD) }\end{array}$ & $\begin{array}{c}\text { Dimensions Contributed by the } \\
\text { Project }\end{array}$ \\
\hline D & 3,807 & 275 & 35 & $70 \%$ & 4,193 & All Dimensions \\
\hline E & 80,545 & 234 & 6 & $68 \%$ & 0 & $\begin{array}{c}\text { Financial, Learning and Growth, } \\
\text { Internal Business }\end{array}$ \\
\hline F & 37,247 & 28 & 0 & $84 \%$ & 0 & All Dimensions \\
\hline G & 53,522 & 154 & 2 & $65 \%$ & 0 & All Dimensions \\
\hline H & 57,719 & 278 & 4 & $87 \%$ & 57,281 & All Dimensions \\
\hline I & 3,790 & 53 & 9 & $95 \%$ & 16,210 & Financial, Learning and Growth, \\
\hline J & 4,525 & 270 & 0 & $96 \%$ & 0 & Customer \\
\hline K & 6,184 & 259 & 0 & $94 \%$ & 0 & Internal Business, Customer \\
\hline L & 91,897 & 254 & 14 & $100 \%$ & 0 & Learning and Growth, Customer \\
\hline Internal Business, Customer
\end{tabular}

Sixteen cases with varying dimension coefficients, budgets, project durations and labour requirement constraints were studied; model outputs are summarised in Table 4. Projects have met the constraints and have the highest outcomes are qualified by the mathematical model. Constraint limits and qualified projects are summarised in Table 4.

Table 4. Results

\begin{tabular}{|c|c|c|c|c|c|}
\hline Case Number & $\begin{array}{c}\text { Budget (B) } \\
\text { (TL) }\end{array}$ & $\begin{array}{c}\text { Time }(T) \\
\text { (hour) }\end{array}$ & Personnel (H) & $\begin{array}{c}\text { Weighted } \\
\text { Dimension } \\
\left(W_{i}=100\right)\end{array}$ & Projects Qualified \\
\hline Case 1 & 50,000 & 500 & 50 & None & $A, I, M$ \\
\hline Case 2 & 100,000 & 500 & 50 & None & $A, F, I, M$ \\
\hline Case 3 & 250,000 & 500 & 50 & None & $A, F, I, M$ \\
\hline Case 4 & 500,000 & 500 & 50 & None & $A, F, I, M$ \\
\hline Case 5 & 150,000 & 300 & 50 & None & $A, C, F, I$ \\
\hline Case 6 & 150,000 & 500 & 50 & None & $A, F, I, M$ \\
\hline Case 7 & 150,000 & 700 & 50 & None & $A, C, F, I, M$ \\
\hline Case 8 & 150,000 & 1000 & 50 & None & $A, C, F, I, J, M$ \\
\hline
\end{tabular}


Table 4. Results (Continued)

\begin{tabular}{cccccc}
\hline Case Number & $\begin{array}{c}\text { Budget (B) } \\
(\text { TL) }\end{array}$ & $\begin{array}{c}\text { Time (T) } \\
\text { (hour) }\end{array}$ & Personnel (H) & $\begin{array}{c}\text { Weighted } \\
\text { Dimension } \\
\left(\mathbf{W}_{\mathbf{i}=100)}\right.\end{array}$ & Projects Qualified \\
\hline Case 9 & 150,000 & 500 & 0 & None & F, J \\
Case 10 & 150,000 & 500 & 10 & None & A, F, M \\
Case 11 & 150,000 & 500 & 25 & None & A, F, I, M \\
Case 12 & 150,000 & 500 & 100 & None & A, F, I, M \\
Case 13 & 100,000 & 1000 & 100 & $\begin{array}{c}\text { Financial } \\
\text { Dimension } \\
\text { Customer }\end{array}$ & A, D, F, I, J, M \\
Case 14 & 100,000 & 1000 & 100 & $\begin{array}{c}\text { Dimension } \\
\text { Internal Business }\end{array}$ & C, F, I, J, K, M \\
Case 15 & 100,000 & 1000 & 100 & $\begin{array}{c}\text { Learning and } \\
\text { Growth }\end{array}$ & A, D, J, F, I, J, M \\
Case 16 & 100,000 & 1000 & 100 & &
\end{tabular}

Sensitivity of the established method to the constraint parameters (time, budget and number of employees) was also analysed.

While varying the budget, the project duration and maximum personnel were constrained to 500 days and 50 employees, respectively; projects $\mathrm{A}, \mathrm{I}$ and $\mathrm{M}$ were selected. These projects had a lower cost and higher total income than expected. If the budget was increased, project $F$ was added into the qualified set. Changes in the set of qualification due to time and personnel were observed after the budget increased to 100,000 TL or more.

To determine the sensitivity of model to project duration, the budget and personnel cap were fixed at 150,000 TL and 50 people, respectively, while project duration was varied. Results indicated a high sensitivity to project time: an increase from 300 days to 500 days allowed for project $M$ to qualify, which had the highest income rate of 9.31 with 314 days duration, rather than project $C$, which had an average income rate of 3.09 with 47 days duration. Thus, extending the time limit allowed the model to qualify projects with the highest income rates while satisfying the other constraints.

Next, the sensitivity of model to the number of personnel was analysed. When no personnel were allowed, projects $\mathrm{F}$ and J were selected. However, no effect was observed between personnel caps at 25 and higher due to the time and budget constraints imposed.

Next, the effect of weighting was examined by including a weight coefficient $(\mathrm{Wj})$ of 100 on varying parameters. When the financial dimension was weighted, projects $A, J$ and $M$ had the highest Ei1 values and were selected. If parameter of customer dimension is more weighted, project $\mathrm{K}$ having the higher customer gaining value qualifies by the model. Similarly, when parameter of internal business points was weighted, the project $K$, with 2.5 times greater $E_{i 3}$ grade (1.31) was replaced with the project $D$, which has $E_{i 3}$ grade (0.56). Projects $C, F, I, J$ and $M$ were qualified due to their high internal business points. When the learning and growth dimension was weighted, project $A$ was included in the qualification list.

\section{Conclusion}

Project selection is a crucial decision that affects the future of an organisation. These decisions determine the effectiveness of resource allocation, progress and short and long-term success. The decision process becomes more complex and thus harder for managers when the number of parameters, options and constraints are increased. Many methods have thus been developed to offer an effective selection tool. 
In this study, an evaluation method was developed to aid in investment and project selection by integrating the BSC technique with the mathematical model of the knapsack problem. The dimensions of BSC method were inserted into the mathematical model. The output points $\left(E_{i j}\right)$ based on pre-assigned success criteria were then calculated for each dimension of individual projects. These points were weighted and summed for each dimension. The mathematical model was written in GAMS software to select the projects that maximise the total outputs. Sample data were generated to represent 13 projects; the performance of the developed model and sensitivity to each parameter was then tested. Test runs were performed on a computer with Windows 10 Pro operating system, a capacity of $8 \mathrm{~GB}$ RAM and a $2.90 \mathrm{GHz}$ processor. Average running time of the model was measured as 0.97 seconds.

The developed model can be used by organisations during project/investment evaluation, resource management, decision-making and direct or indirect review of outputs. The model was found to generate consistent results; it includes budget, personnel and time constraints and is open to the addition of new constraints and parameters. Therefore, it can prevent exceeding available resources. Additional constraints can be added to the model in future studies to represent entire organisational structures, strategic targets and specific requirements.

\section{References}

Asosheh, A., Nalchigar, S., \& Jamporazmey, M. (2010). Information technology project evaluation: An integrated data envelopment analysis and balanced scorecard approach. Expert Systems with Applications, (37), 5931-5938.

Bailey, A. R., Chow, C. W., \& Haddad, K. M. (1999). Continuous improvement in business education: Insights from the for-profit sector and Business School Deans. Journal of Education for Business, 74(3), 165-180.

Basık, F. O. (2012). Rekabet stratejisinde maliyet yönetimi. İstanbul: Türkmen Kitabevi.

Bhagwat, R., \& Sharma, M. K. (2007). Performance measurement of supply chain management: A balanced scorecard approach. Computers \& Industrial Engineering, (53), 43-62.

Chang, P. T., \& Lee, J. H. (2012). A fuzzy DEA and knapsack formulation integrated model for project selection. Computers and Operations Research, 39, 112-125.

Eilat, H., Golany, B., \& Shtub, A. (2008). R\&D project evaluation: An integrated DEA and balanced scorecard approach. Omega, (36), 895-912.

Güner, M. F. $(2008,10$ 1). Bir stratejik yönetim modeli olarak Balanced Scorecard. Gazi Üniversitesi iktisadi ve Idari Bilimler Fakültesi Dergisi, 10(1), 247-265.

Kaplan, R. S., \& Norton, D. P. (1992, January-February). The balanced scorecard: Measures that drive performance. Harvard Business Review, 70(1), 71-79.

Kaygusuz, S. Y. (2005). Yönetim muhasebesinin performans yönetimi fonksiyonunda geldiği son nokta: Balanced Scorecard. İș, Güç, Endüstri Iliş̧kileri ve Insan Kaynakları Dergisi, 7(1), 81-103.

Mostamand, M., Hajiagha, H., \& Daneshvar, M. (2017). Selecting strategies by considering budget limitation: A hybrid algorithm of SWOT-DEMATEL-ANP and binary programming with grey information. Informatica, 28(3), 485-503.

Shafiee, M., Lotfi, F. H., \& Saleh, H. (2014). Supply chain performance evaluation with data envelopment analysis and balanced scorecard approach. Applied Mathematical Modeling, 38(21), 5092-5112.

Simplicio, R., Gomes, J., \& Romao, M. (2017). Projects selection and prioritization: A Portuguese Navy Pilot Model. Procedia Computer Science, 121, 72-79.

Singh, S., Olugu, E., Musa, S., \& Mahat, A. B. (2018). Fuzzy-based sustainability evaluation method for manufacturing SMEs using balanced scorecard framework. Journal of Intelligent Manufacturing, 29(1), 1-18.

Tan, Y., Zhang, Y., \& Khodaverdi, R. (2017). Service performance evaluation using Data Envelopment Analysis and Balance Scorecard Approach: An application to automotive industry. Annals of Operations Research, 248(1), 449470. 